\title{
Microbiological pollution and some physicochemical properties of sıkaraağaçlar creek in sinop (Black Sea-Turkey)
}

\author{
Ayşe GÜNDOĞDU ${ }^{1 *}$ (D), Ŭgur ÇARLI ${ }^{2}$ (iD) \\ ${ }^{1}$ Fisheries Faculty, Sinop University, Sinop, Turkey \\ ${ }^{2}$ Scientific and Technological Researchs Application and Research Center, Sinop University, Sinop, Turkey
}

\begin{abstract}
Sırakaraağaçlar creek located in Akliman of Sinop city. It is born within the province of Sinop and discharges from the Akliman coastline to the Black Sea. The work continued from May 2014 to April 2015. Four stations were stated in the study. To determine the quality of water, some physicochemical features and microbiological analysis of creek water was determined. These are temperature, dissolved oxygen, $\mathrm{pH}$, conductivity, biological oxygen demand, ammonium nitrogen, hydrogen sulfide, organic matter, total suspended solids parameters, and Total coliform and Fecal coliform values. When the T. coliform and F. coliform values of Surakaraağaçlar Creek were examined seasonally, the minimum values were found as $35.88 \pm 1.48 \mathrm{cfu} / 100 \mathrm{ml}$ and $27.33 \pm 1.25 \mathrm{cfu} / 100 \mathrm{ml}$ at $\mathrm{S} 1$ station in Winter, and the maximum values were $1263.55 \pm 184.57 \mathrm{cfu} / 100 \mathrm{ml}$ and $1020.22 \pm 105.29 \mathrm{cfu} / 100 \mathrm{ml}$ at $\mathrm{S} 4$ station in Summer, respectively. The results obtained from the creek water were classified according to the regulations of Turkey's Surface Water Quality Management. It was evaluated whether the perimeter of the creek had any effect on the water source.
\end{abstract}

\author{
Article info \\ History: \\ Received:08.01.2020 \\ Accepted:30.06.2020 \\ Keywords: \\ Coliform, \\ River, \\ Physicochemical, \\ Sinop, \\ Black Sea.
}

\section{Introduction}

The quality of surface waters both flowing and stagnant is very important to the natural environment and humans, and for this reason, it should be assessed specific physical, biological, chemical and microbiological characteristics $[1,2]$. Water is a specific and natural resource that is essential for all living organisms. It is both exhaustible and renewable resources, as when consumed or polluted in a given place and time, its quantity and quality can be restored under appropriate conditions [3]. Today, all water resources around the world are at risk of pollution and extinction. This situation can be attributed to tourism activities, domestic and industrial waste. Besides, it is possible to show climate changes and drought brought about by global warming. As a result of these negative factors, water resources are rapidly decreasing [4, 5]. For this reason, the protection of the proper water status and provision of sustainability is becoming increasingly important.

Water quality is deceived by both microbiological and physicochemical properties. Moreover, chemical and biochemical reactions such as decomposition, hydrolysis, dissolution, adsorption, sedimentation and ion exchange, reduction, oxidation processes that are important control factors for surface and groundwater structure [6].Evaluation of physicochemical parameters such as $\mathrm{PH}$, conductivity, total suspended solids, alkalinity, hydrogen sulfide, organic matter, ammonium and nitrate are generally considered to be guiding principles and classify physicochemical water quality. In microbiological analysis, definition of indicator bacteria like Total coliform (T. coliform), Fecal coliforms (F. coliform), Enterococcus, Fecal streptococci, and Escherichia coli are generally performed to

evaluate the possibility of fecal contamination and to qualify the source for usable [7-9]. The total number of coliform bacteria is used as the most reliable indicator of water quality. Coliform bacteria may be found in human and animal intestines as well as in the environment. They may be indicative of potential fecal contamination. F. coliform and E. coli are found only in human and animal gut, and tests for their presence in the water are necessary to confirm fecal contamination of humans or other warm-blooded animals. $[10,11]$. This kind of contamination means that any normal flora and pathogenic microorganisms that take place in the intestinal tract of these animals may also be formed [12].The members of the genus Escherichia comprise more than $60 \%$ of the $\mathrm{T}$. 
coliforms and more than $90 \%$ of the F. coliforms. One of the most important coliform bacteria is E. coli. Several types of this species are opportunistic pathogens and may be the cause of the disease [13]. The indicator-microorganisms are coliform bacteria which are disunited into $F$. coliform and non-F. coliform. E. coli that is found in the normal flora in the human and other warm-blooded animals intestinal tract, it is feces type of Enterobacteria. The non-fecal type contains Enterobacter aerogens that are widely dispersed in nature and are sometimes found in the intestinal tract of warm-blooded organisms [12]. These bacteria are a part of the natural river mouth microflora and can be accumulated by shellfish during feeding $[14,15]$.

The microorganisms present in the water ecosystem are either mixed into the water from various ways or are formed according to the environmental conditions. Microorganisms can come to natural waters from the atmosphere and soil, and they can also be of industrial and domestic waste origin [16-18].

Microorganisms in water are grouped into three groups. Microorganisms naturally found in water: Spirillum, Vibrio, Pseudomanas, Achromobacter, Chromobacter species and some species of Micrococcus and Sarcina. Soil-based microorganisms: They are mixed with water as the water passes through the soil layers or as a result of washing the soil with. They are Bacillus, Streptomyces and saprophyte members of Enterobacteriaceae. Microorganisms of human and animal origin: Principles; E. coli, Streptococcus faecalis, Clostridium perfringens and other intestinal pathogens. Such microorganisms may cause harmful, dangerous, and disease-causing as well as cause changes in the biochemical structure of water resources [19-21]. High concentrations of sewage bacteria are a potential threat to human health in the event of sewage permeation into the environment. As intestinal bacteria, a special pathogenic property is exhibited by gram-negative Salmonella, including those that cause typhoid. [22, 23]. These microorganisms can cause many problems which are fever, nausea, vomiting, diarrhea, and they may also be the cause of death [24, 25].

Our study aims to assess the amount of T. coliform and F. coliform bacteria in the surface waters of Sirakaraağaçlar Creek. Further, an attempt to look for the correlation between the selected physicochemical variables of water quality and the quantitative occurrence of tested bacterial groups in these waters was determined. Surface water quality is of great importance for the economy due to microbiological indicators because legal standards are governing their monitoring and protection. Furthermore, to ensure the sustainability of natural waters, it is necessary to continuously identify and monitor its properties.

\section{Material and Methods}

The study was conducted seasonally from May 2014 to April 2015. Four different stations were identified to represent Sırakaraağaçlar Creek. Water samples were collected in sterile brown bottles from each of the stations identified along the river and transported to the laboratory for analysis. Field surveys were conducted at the surface water of sampling stations in monthly periods, and some physical and chemical parameter measurements were performed.

\subsection{Characteristics of the evaluation area}

Karagöl-Aksaz Swamp is a swamp system formed when the front of an old gulf is closed with coastal dunes, and lagoon lakes that have been formed have turned into a terrestrial structure over time. The area of the area is approximately 300 ha. Karasu Stream feeds Karagöl Swamp, which started after Sinop Airport. The Aksaz Reeds, which is located in the northeast of Karagöl Swamp, feeds the Sıkaraağaçlar Creek, where smaller streams are also included. The swamp and reed unit distinguishes it from the sea with a coastal language of about $4100 \mathrm{~m}$ in length and up to $130 \mathrm{~m}$ in places [26]. The terrestrial area side of the dunes that make up the coastal language is covered with a rich dune vegetation (vegetation is the formation of reed, straw and similar plant groups or algae in the water growing in swamps). In the swamp and reed area, the wetland vegetation is enriched with the rise of the ground water level in the winter months [27, 28]. The average depth of the stream is $1.5 \mathrm{~m}$, and the maximum depth is $2.5 \mathrm{~m}$. While the bottom of stream has a muddy structure, its part opening to the sea has a sandy structure [29].

Four stations with different characteristics were determined in the Sırakaraağaçlar stream. S1 station: It is located in the Akliman area of Sinop where the creek meets the sea. In this region where the creek is poured into the sea, it is known that seawater occasionally enters from the creek mouth. The station is at the point where freshwater and saltwater mix, the sediment is covered with fine sand. It was chosen to reveal the effects of the sea on the stream and other environmental effects. S2 station: This station is located to the north-east of Aksaz swamp, the stream water is turbid, muddy and the surrounding area is covered with reeds. It is located within the settlements, also in the region where there are official institutions and various businesses and where maritime tourism 
takes place. However, the settlement area is within the provincial borders of Sinop (central) and there is a sewage system. For this reason, domestic waste cannot be left to the S1 and S2 stations. S3 station: It is an area dominated by reeds and swamps. The water of the stream is turbid and muddy. $\mathrm{S} 4$ station: Although there is no settlement around the station, it is known that the village of Abalı is located $50-60 \mathrm{~m}$ away and the village does not have a sewage system. Domestic waste is mixed into the stream of S1karaağaçlar from this region. Moreover, it is known that there are agricultural lands around the village of Aball, and animal husbandry is carried out (Figure 1).

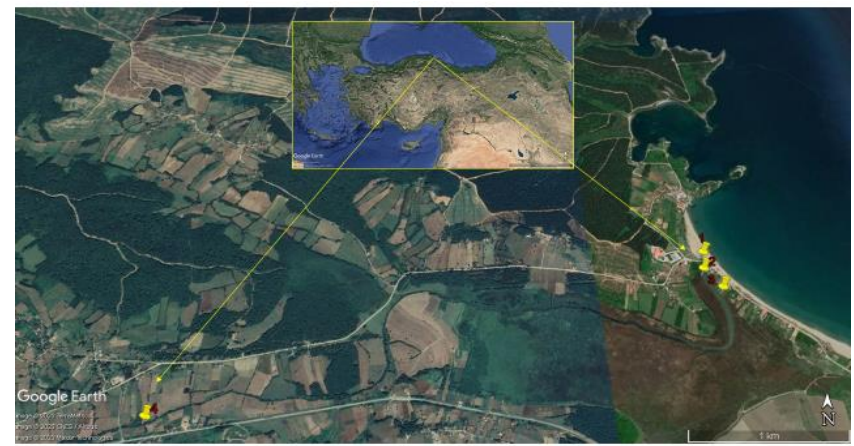

Figure 1. Sampling stations of Strakaraağaçlar Creek

(S1: $42^{\circ} 02^{\prime} 28.76^{\prime \prime N}-35^{\circ} 02^{\prime} 39.79 " \mathrm{E}, \quad \mathrm{S} 2: \quad 42^{\circ} 02^{\prime} 24.42^{\prime \prime} \mathrm{N}-$ $35^{\circ} 02^{\prime} 38.90^{\prime \prime E}, \mathrm{~S} 3: 42^{\circ} 02^{\prime} 19.62^{\prime} \mathrm{N}-35^{\circ} 02^{\prime} 43.52^{\prime \prime} \mathrm{E}$ and S4: $\left.42^{\circ} 01^{\prime} 49.59^{\prime \prime} \mathrm{N}-34^{\circ} 599^{\prime} 58.44^{\prime \prime} \mathrm{E}\right)$.

\subsection{Physicochemical Parameters}

In the study, with the aim of determine the quality of water, temperature $\left({ }^{\circ} \mathrm{C}\right)$, dissolved oxygen $(\mathrm{DO}, \mathrm{mg} / \mathrm{L})$, $\mathrm{pH}$, conductivity $(\mu \mathrm{s} / \mathrm{cm})$, biological oxygen demand $\left(\mathrm{BOD}_{5}, \mathrm{mg} / \mathrm{L}\right)$, ammonium nitrogen $\left(\mathrm{NH}_{4}{ }^{+}-\mathrm{N}, \mathrm{mg} / \mathrm{L}\right)$, hydrogen sulfide $\left(\mathrm{H}_{2} \mathrm{~S}, \mathrm{mg} / \mathrm{L}\right)$, organic matter $(\mathrm{OM}$, $\mathrm{mg} / \mathrm{L}$ ), total suspended solids (TSS, mg/L) parameters were selected. Temperature, DO, $\mathrm{pH}$ and conductivity measurements were performed with YSI Multiparameter (Professional Plus model) device in sampling areas. While taking the water samples, the sample containers were filled with a dip of $30-40 \mathrm{~cm}$ upside down relative to the water surface and held at $45^{\circ}$ slopes. The other physicochemical analyses were held in laboratory conditions. Measurement and analysis of $\mathrm{BO}_{5}, \mathrm{NH}_{4}{ }^{+}-\mathrm{N}, \mathrm{H}_{2} \mathrm{~S}, \mathrm{OM}$ and TSS were made by applying Standard Methods which are valid for waters. Parametric measurement results were obtained by using the Titrimetric method for $\mathrm{BOD}_{5}$ and $\mathrm{H}_{2} \mathrm{~S}$, Spectrophotometric method(RAYLEIGH UV726) for $\mathrm{NH}_{4}{ }^{+}-\mathrm{N}$, Gravimetric method for $\mathrm{OM}$ and TAKM [30-33].

\subsection{Microbiological Analysis}

For microbial analysis of the creek, water samples were collected separately in sterile containers from stations. The sample cups were immersed upside down to a depth of $20-30 \mathrm{~cm}$ concerning the water surface, and filled with a $45^{\circ}$ inclination. Microbiological analysis samples were transported to the laboratory under ice-cooled conditions. Total (T.) coliform and fecal (F.) coliform values (cfu/100 ml) were determined for microbial evaluation. To this end, samples reduced to a dilution of $10^{3}$ in $100 \mathrm{ml}$ sterile sample cups were analyzed by membrane filtration method in triplicate. Water samples were filtered through strainers with pore diameter $0.45 \mu \mathrm{m}$ utilizinga vacuum pump. Filter papers were placed on the prepared culture media and incubated at appropriate temperatures. In the study, ENDO agar for T. coliforms and $\mathrm{m}-\mathrm{FC}$ agar nutrient pad systems for $\mathrm{F}$. coliforms were used. The media containing the filters were evaluated after a 24 hour waiting period at $37 \pm 0.1{ }^{\circ} \mathrm{C}$ for T. coliforms and $44.5 \pm 0.1{ }^{\circ} \mathrm{C}$ for F. coliforms. Dark red, metallic green colonies developed on ENDO agar were evaluated as T. coliform, and blue colonies grown on $\mathrm{m}$-FC agar were F. coliform. T. coliform and F. coliform bacteria were detected at all stations, and the results were recorded as cfu/100 ml [34].

\subsection{Statistical Analysis}

Statistical analyses of water quality parameters are calculated with SPSS 22 and Minitab 18 program. Two-way ANOVA test was used to determine whether all parameters differ between stations and seasons. Tukey test was also used to determine the differences in the tests. Physicochemical parameters were found to be statistically significant according to $\mathrm{P}<0.05$. Besides, correlation matrices were established to evaluate the relationships between the obtained results. Correlation coefficients between physicochemical parameters and coliform bacteria were evaluated.

\section{Results and Discussion}

Coliform bacteria and some physicochemical parameters (Figure 2, 3). of the Sırakaraağaçlar stream have been shown in Table 1-4. Microbiological evaluation of the creek was determined by investigating the presence of $\mathrm{T}$. coliform and $\mathrm{F}$. coliform bacteria. The minimum and maximum of the T. coliform values were found to be $30-245,106-535$, $87-439$ and 128-1904 cfu/100 ml at S1, S2, S3 and S4 stations, respectively. Minimum and maximum of F. coliform levels were determined as 22-200, 90-452, 
87-304 and 72-1394 cfu/100 ml in S1, S2, S3 and S4 stations, respectively.In this study, a statistically significant difference $(\mathrm{P}<0.05)$ was found between the seasonal mean values, and also between the mean values of the stations( $\left(\mathrm{DO}, \mathrm{BOD}_{5}, \mathrm{NH}_{4}^{+}-\mathrm{N}, \mathrm{OM}, \mathrm{T}\right.$. coliform and $\mathrm{F}$. coliform). While values of temperature, $\mathrm{pH}$ and $\mathrm{H}_{2} \mathrm{~S}$ were significantly different from season to season, the conductivitiy was different from station to station $(\mathrm{P}<0.05)$. Besides, the suspended solids did not show differences $(\mathrm{P}>0.05)$ both in terms of stations and seasonally (Table 1-4).Correlation coefficients between physicochemical parameters and coliform bacteria are shown according to $\mathrm{P}<0.05$, $\mathrm{P} \leq 0.01$ and $\mathrm{P} \leq 0.001$ in Table 5.

The lowest and the highest temperature in Sirakaraağaçlar Creek was $12.45^{\circ} \mathrm{C}$ and $26.98{ }^{\circ} \mathrm{C}$ at S3 station, respectively. It is known that the temperature value of the water source varies depending on climate, height, flow rate and bed structure of water source, atmospheric conditions [35]. Temperature, which is one of the main parameters in water quality studies, although it does not seem to make sense by itself, creates meaningful integrity with other parameters such as dissolved oxygen, biological oxygen need, pH, etc. [36]. Tepe and Mutlu [37] reported that the average temperature was $15.70{ }^{\circ} \mathrm{C}$ in Hatay Harbiye spring water, In another study, Bulut, Akçimen, Uysal, Küçükkara, Savaşer, Tokatl, Öztürk and Köse [38] showed that the optimum values were between 11.31 and $12.05{ }^{\circ} \mathrm{C}$ for temperature in the stations of Kestel Creek, and Y1ld1z [39] determined that the temperature was $13.19^{\circ} \mathrm{C}$ in a conducted study on the Gelevera Creek of Giresun province. Our results were found to be parallel with the results of these studies conducted at different times in different regions.

When the seasonal variations of DO values of Sirakaraağaçlar Creek were examined, the lowest value was measured at $\mathrm{S} 4$ station with $1.56 \mathrm{mg} / \mathrm{L}$ in Summer (Figure 2). Since the S4 station is under the influence of the Abalı village sewage and agricultural areas located nearby, the oxygen level is quite low in the summer period. There are areas classified as marshes around the stream. In the region, animal husbandry is carried out, and animals have grazing areas. In our working period, we did not have access to any death information about fish or other species. But, Karsl1 [40] reported that fish (A. Chantrei) could not be obtained from the sampling area during the months of November-April due to the negative effects on the environment and water conditions in the study conducted in the Sirakaraağaçlar stream between June 2005 and May 2006. They emphasized that irregular changes in the characteristics of the water in this region depending on the seasons negatively affect the fish population and the breeding amount. The highest value was detected at $\mathrm{S} 1$ station with $5.23 \mathrm{mg} / \mathrm{L}$ in Winter. It was determined that the DO values, seasonal air and water temperatures were affected by the change, and the highest concentration of DO in the water was in winter. This confirms that the solubility of gases is inversely proportional to temperature. Oxygen gas is the most important gas dissolved in water. The solubility of oxygen in water varies depending on temperature, salinity, photosynthetic activities and atmospheric pressure [41,42]. When the seasonal variations of $\mathrm{DO}$ values of Sirakaraağaçlar Creek are analyzed according to the Classes of Continental Water Resources, water quality in II. and IV. class (Table 6). According to the data of the World Health Organization (WHO), the DO value of river waters should be $\geq 5 \mathrm{mg} / \mathrm{L}$. In our study, all DO data were found under the WHO standards [43]. According to the Water Framework Directive of the European Union, the $\mathrm{DO}$ value in the range of $2-6 \mathrm{mg} / \mathrm{L}$ is indicated as inadequacy [44]. DO values obtained as a result of our study correspond to this range.In this case, it can be considered that the DO values of the water source are low and may adversely affect the water ecosystem. DO concentration helps us to have an idea about the pollution potential of water, the amount of OM in it and the degree of self-cleaning of water [45]. In the study was conducted by Taşdemir and Göksu in Asi River [46], the amount of DO was determined between 2.6 and $9.9 \mathrm{mg} / \mathrm{L}$. In the studies were carried out in Hatay Karamanlı Pond [47] and Trabzon İyidere River [48], they found average DO concentration of $9.31 \mathrm{mg} / \mathrm{L}$ and $11.10 \mathrm{mg} \mathrm{L}$, respectively. The DO values obtained from our study differ from the previous studies can be explained with the regional differences being effective. Additionally, it shows that environmental effects are high in the Sırakaraağaçlar stream and that it is facing a pollution problem.

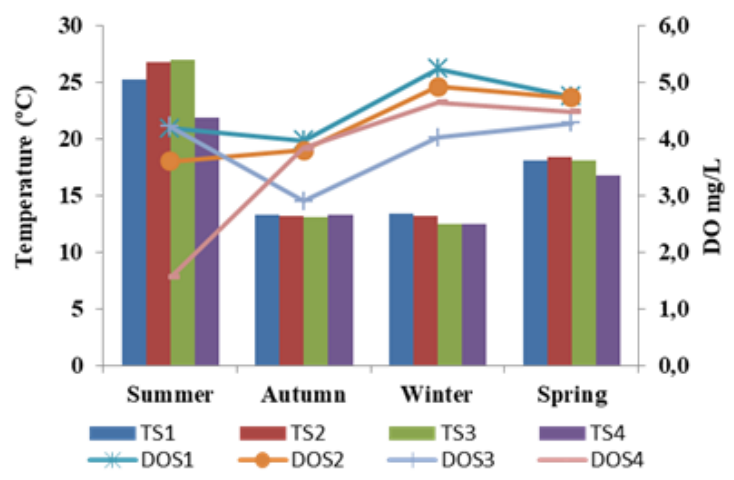

Fig. 2. Seasonal changes of temperatures and DO values of Creek. 
Table 1.Values ( $\mathrm{X} \pm \mathrm{SD}$; min-max) of physicochemical parameters of Creek.

\begin{tabular}{|c|c|c|c|c|c|}
\hline \multicolumn{2}{|c|}{ Stations } & \multirow{2}{*}{ n Summer } & \multirow{2}{*}{$\begin{array}{l}\text { Autumn } \\
13.30 \pm 0.90^{\mathrm{aB}}\end{array}$} & \multirow{2}{*}{$\begin{array}{l}\text { Winter } \\
13.37 \pm 0.60^{\mathrm{aB}}\end{array}$} & \multirow{2}{*}{$\frac{\text { Spring }}{18.13 \pm 0.24^{\mathrm{aC}}}$} \\
\hline \multirow{8}{*}{ 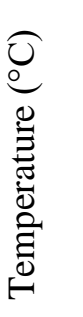 } & & & & & \\
\hline & $S 1$ & 9 (22.03-28.47) & $(10.55-16.80)$ & (11.20-15.49) & (17.17-18.97) \\
\hline & S? & $26.80 \pm 0.40^{\mathrm{aA}}$ & $13.21 \pm 0.82^{\mathrm{aB}}$ & $13.24 \pm 0.59^{\mathrm{aB}}$ & $18.44 \pm 0.46^{\mathrm{aC}}$ \\
\hline & $\mathrm{S} 2$ & $9(25.39-28.30)$ & $(10.80-16.40)$ & (11.14-15.38) & $(16.92-20.22)$ \\
\hline & & $26.98 \pm 0.39^{\mathrm{a} A}$ & $13.13 \pm 0.80^{\mathrm{aB}}$ & $12.45 \pm 0.42^{\mathrm{aB}}$ & $18.11 \pm 0.61^{\mathrm{aC}}$ \\
\hline & S3 & $9 \quad(25.45-28.34)$ & $(10.96-16.29)$ & $(11.09-14.09)$ & $(16.20-20.46)$ \\
\hline & $\mathrm{S} 4$ & $21.85 \pm 0.36^{\mathrm{aA}}$ & $13.27 \pm 0.76^{\mathrm{aB}}$ & $12.50 \pm 0.43^{\mathrm{aB}}$ & $16.79 \pm 0.19^{\mathrm{aC}}$ \\
\hline & $S 4$ & $9 \quad(22.30-22.85)$ & $(10.85-16.19)$ & (11.02-14.09) & $(16.22-17.62)$ \\
\hline \multirow{8}{*}{ 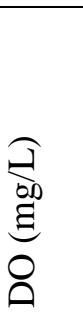 } & & $4.18 \pm 0.25^{\mathrm{abA}}$ & $3.97 \pm 0.40^{\mathrm{abB}}$ & $5.23 \pm 0.06^{\mathrm{abC}}$ & $4.75 \pm 0.09^{\mathrm{abC}}$ \\
\hline & SI & $9 \quad(3.20-5.40)$ & $(2.30-5.00)$ & $(5.00-5.50)$ & $(4.20-5.00)$ \\
\hline & S? & $3.60 \pm 0.06^{\mathrm{abA}}$ & $3.80 \pm 0.30^{\mathrm{abB}}$ & $4.92 \pm 0.07^{\mathrm{abC}}$ & $4.72 \pm 0.15^{\mathrm{abC}}$ \\
\hline & $\mathrm{SL}$ & $9 \quad(3.40-4.00)$ & $(2.50-4.70)$ & $(4.60-5.30)$ & $(4.10-5.40)$ \\
\hline & $\mathrm{S}_{3}$ & $4.22 \pm 0.61^{\mathrm{bA}}$ & $2.90 \pm 0.33^{\mathrm{bB}}$ & $4.02 \pm 0.08^{\mathrm{bC}}$ & $4.28 \pm 0.18^{\mathrm{bC}}$ \\
\hline & 53 & $9(2.20-6.60)$ & $(1.50-3.90)$ & $(3.60-4.40)$ & $(3.60-5.20)$ \\
\hline & & $1.56 \pm 0.24^{\mathrm{bA}}$ & $3.84 \pm 0.19^{\mathrm{bB}}$ & $4.64 \pm 0.07^{\mathrm{bC}}$ & $4.48 \pm 0.09^{\mathrm{bC}}$ \\
\hline & S4 & $9(0.60-2.60)$ & $(3.00-4.40)$ & $(4.30-4.90)$ & $(4.20-5.00)$ \\
\hline \multirow{8}{*}{$\stackrel{\mathbb{I}}{2}$} & S1 & $8.11 \pm 0.12^{\mathrm{aA}}$ & $7.57 \pm 0.06^{\mathrm{aB}}$ & $7.19 \pm 0.01^{\mathrm{aC}}$ & $7.29 \pm 0.14^{\mathrm{aC}}$ \\
\hline & $\mathrm{SI}$ & 9 (7.77-8.64) & $(7.40-7.86)$ & $(7.12-7.28)$ & $(6.75-7.82)$ \\
\hline & $\mathrm{S} ?$ & $8.37 \pm 0.04^{\mathrm{aA}}$ & $7.64 \pm 0.07^{\mathrm{aB}}$ & $7.14 \pm 0.02^{\mathrm{aC}}$ & $7.37 \pm 0.13^{\mathrm{aC}}$ \\
\hline & $\mathrm{S} 2$ & (8.25-8.57) & $(7.33-7.86)$ & $(7.07-7.22)$ & $(6.87-7.79)$ \\
\hline & & $8.32 \pm 0.02^{\mathrm{aA}}$ & $7.63 \pm 0.08^{\mathrm{aB}}$ & $7.15 \pm 0.02^{\mathrm{aC}}$ & $7.31 \pm 0.12^{\mathrm{aC}}$ \\
\hline & S3 & $9(8.21-8.45)$ & $(7.28-7.89)$ & $(7.07-7.25)$ & $(6.79-7.63)$ \\
\hline & & $7.79 \pm 0.01^{\mathrm{aA}}$ & $7.78 \pm 0.10^{\mathrm{aB}}$ & $7.15 \pm 0.03^{\mathrm{aC}}$ & $7.25 \pm 0.13^{\mathrm{aC}}$ \\
\hline & S4 & $9(7.72-7.86)$ & $(7.30-8.03)$ & $(7.07-7.29)$ & $(6.70-7.58)$ \\
\hline \multirow{8}{*}{ 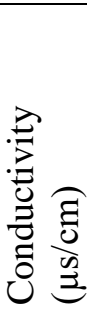 } & & $612.57 \pm 122.70^{\mathrm{bA}}$ & $1004.71 \pm 31.01^{\mathrm{bA}}$ & $937.80 \pm 2.63^{\mathrm{bA}}$ & $669.55 \pm 139.68^{\mathrm{bA}}$ \\
\hline & SI & ${ }^{9}(224.85-1067.18)$ & $(889.2-1102.11)$ & $(928.65-946.96)$ & $(110.80+955.37)$ \\
\hline & S? & $216.88 \pm 18.00^{\mathrm{cA}}$ & $475.74 \pm 8.41^{\mathrm{cA}}$ & $429.13 \pm 6.52^{\mathrm{cA}}$ & $405.26 \pm 71.49^{\mathrm{cA}}$ \\
\hline & $\mathrm{S} 2$ & $(178.6-288.88)$ & $(444.60-502.50)$ & $(408.80-453.55)$ & $(119.32-554.80)$ \\
\hline & $S_{3}$ & $200.80 \pm 10.87^{\mathrm{dA}}$ & $199.64 \pm 9.17^{\mathrm{dA}}$ & $223.34 \pm 3.98^{\mathrm{dA}}$ & $232.34 \pm 31.05^{\mathrm{dA}}$ \\
\hline & $\mathrm{S3}$ & $(176.7-244.29)$ & $(173.20-234.96)$ & $(208.20-235.60)$ & $(110.85-315.9)$ \\
\hline & & $20.11 \pm 2.30^{\mathrm{aA}}$ & $78.72 \pm 9.54^{\mathrm{aA}}$ & $44.10 \pm 2.64^{\mathrm{aA}}$ & $75.19 \pm 16.83^{\mathrm{aA}}$ \\
\hline & S4 & $9(11.18-26.7)$ & $(57.70-116.89)$ & $(34.86-53.26)$ & $(8.30-115.52)$ \\
\hline \multirow{8}{*}{ 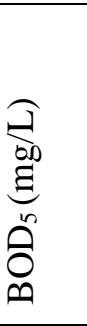 } & & $1.02 \pm 0.16^{\mathrm{bA}}$ & $3.10 \pm 0.41^{\mathrm{bB}}$ & $2.05 \pm 0.04^{\mathrm{bA}}$ & $2.24 \pm 0.34^{\mathrm{bA}}$ \\
\hline & S1 & $9(0.40-1.80)$ & $(2.00-4.80)$ & $(1.90-2.30)$ & $(1.60-2.60)$ \\
\hline & $\mathrm{S}_{2}$ & $1.15 \pm 0.24^{\mathrm{bA}}$ & $4.02 \pm 0.29^{\mathrm{bB}}$ & $3.15 \pm 0.05^{\mathrm{bA}}$ & $3.13 \pm 0.17^{\mathrm{bA}}$ \\
\hline & $\mathrm{S} 2$ & ${ }^{9}(0.20-2.00)$ & $(3.30-5.40)$ & $(3.00-3.50)$ & $(2.40-3.65)$ \\
\hline & $\mathrm{S}_{3}$ & $1.06 \pm 0.21^{\mathrm{abA}}$ & $2.14 \pm 0.26^{\mathrm{abB}}$ & $1.28 \pm 0.02^{\mathrm{abA}}$ & $1.43 \pm 0.10^{\mathrm{abA}}$ \\
\hline & S3 & ${ }^{9}(0.20-2.00)$ & $(1.50-3.40)$ & $(1.20-1.40)$ & $(0.80-1.80)$ \\
\hline & S4 & $9^{0.84 \pm 0.14^{\mathrm{bA}}}$ & $4.42 \pm 0.51^{\mathrm{bB}}$ & $2.33 \pm 0.02^{\mathrm{bA}}$ & $2.82 \pm 0.13^{\mathrm{bA}}$ \\
\hline & S4 & $9(0.40-1.60)$ & $(2.54-6.20)$ & $(2.24-2.50)$ & $(2.36-3.60)$ \\
\hline
\end{tabular}

A, B, C : The letters show differ between seasons (P <0.05); a, b, c The letters show differ between stations $(\mathrm{P}<0.05)$.

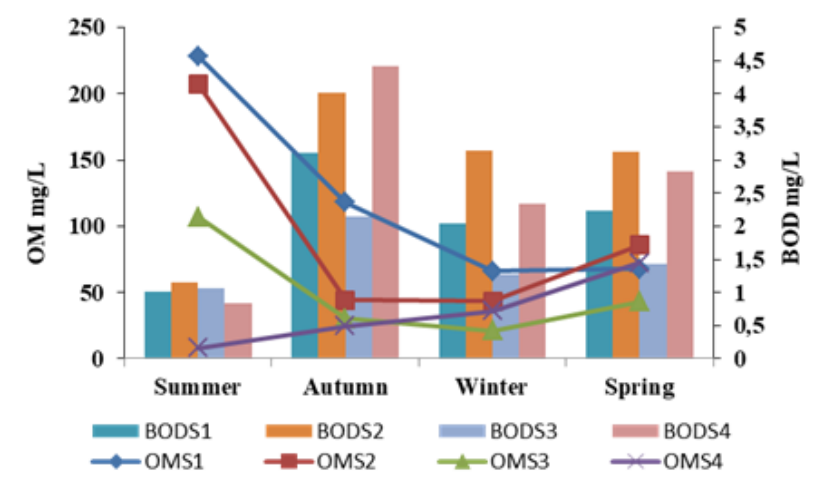

Fig. 3. Seasonal changes of $\mathrm{OM}$ and $\mathrm{BOD}_{5}$ values of Creek. 
Table 3. Values $(X \pm S D$; min-max $)$ of $\mathrm{T}$. coliform of Creek.

\begin{tabular}{|c|c|c|c|c|c|c|}
\hline & Stations & $\mathrm{n}$ & Summer & Autumn & Winter & Spring \\
\hline \multirow{8}{*}{ 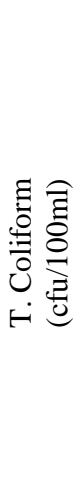 } & \multirow{2}{*}{ S1 } & \multirow{2}{*}{9} & $214.66 \pm 8.88^{\mathrm{aA}}$ & $98.22 \pm 4.10^{\mathrm{aB}}$ & $35.88 \pm 1.48^{\mathrm{aC}}$ & $83.22 \pm 3.53^{\mathrm{aB}}$ \\
\hline & & & $(180-245)$ & $(82.113)$ & $(30-41)$ & $(69-96)$ \\
\hline & \multirow{2}{*}{ S2 } & \multirow{2}{*}{9} & $470.77 \pm 16.14^{\mathrm{bA}}$ & $326.55 \pm 8.07^{\mathrm{bB}}$ & $119.44 \pm 3.20^{\mathrm{bC}}$ & $144.33 \pm 4.00^{\mathrm{bB}}$ \\
\hline & & & $(405-535)$ & $(303-363)$ & $(106-134)$ & $(132-169)$ \\
\hline & \multirow{2}{*}{ S3 } & \multirow{2}{*}{9} & $337.66 \pm 27.91^{\mathrm{abA}}$ & $194.11 \pm 15.23^{\mathrm{abB}}$ & $132.55 \pm 12.5^{\mathrm{abC}}$ & $221.11 \pm 18.96^{\mathrm{abB}}$ \\
\hline & & & $(241-439)$ & $(140-256)$ & $(87-183)$ & $(158-298)$ \\
\hline & \multirow{2}{*}{ S4 } & \multirow{2}{*}{9} & $1263.55 \pm 184.57^{\mathrm{cA}}$ & $401.00 \pm 11.82^{\mathrm{cB}}$ & $134.66 \pm 1.75^{\mathrm{cC}}$ & $687.11 \pm 4.74^{\mathrm{cB}}$ \\
\hline & & & (616-1904) & $(358-452)$ & $(128-144)$ & $(673-708)$ \\
\hline
\end{tabular}

A, B, C : The letters show differ between seasons ( $\mathrm{P}<0.05)$; $a, b, c$ The letters show differ between stations $(\mathrm{P}<0.05)$.

Table 4.Values (X $\pm \mathrm{SD}$; min-max) of F. coliform of Creek.

\begin{tabular}{|c|c|c|c|c|c|c|}
\hline & tations & $\mathrm{n}$ & Summer & Autumn & Winter & Spring \\
\hline \multirow{8}{*}{ 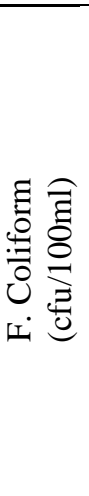 } & \multirow{2}{*}{ S1 } & \multirow{2}{*}{9} & $182.22 \pm 4.74^{\mathrm{aA}}$ & $76.77 \pm 5.10^{\mathrm{aB}}$ & $27.33 \pm 1.25^{\mathrm{aC}}$ & $50.22 \pm 1.36^{\mathrm{aB}}$ \\
\hline & & & $(158-200)$ & $(59-101)$ & $(22-33)$ & $(43-56)$ \\
\hline & & \multirow{2}{*}{9} & $430.11 \pm 7.40^{\mathrm{bA}}$ & $255.66 \pm 13.91^{\mathrm{bB}}$ & $101.77 \pm 3.04^{\mathrm{bC}}$ & $122.77 \pm 4.18^{\mathrm{bB}}$ \\
\hline & & & $(395-452)$ & $(200-300)$ & $(90-111)$ & $(102-138)$ \\
\hline & \multirow{2}{*}{ S3 } & \multirow{2}{*}{9} & $276.55 \pm 11.29^{\mathrm{bA}}$ & $172.11 \pm 18.09^{\mathrm{bB}}$ & $104.66 \pm 3.92^{\mathrm{bC}}$ & $128.66 \pm 9.55^{\mathrm{bB}}$ \\
\hline & & & $(240-304)$ & (98-224) & $(87-122)$ & $(145-221)$ \\
\hline & & \multirow{2}{*}{ c } & $1020.22 \pm 105.29^{\mathrm{dA}}$ & $380.33 \pm 11.43^{\mathrm{dB}}$ & $86.22 \pm 2.94^{\mathrm{dC}}$ & $539.11 \pm 13.86^{\mathrm{dB}}$ \\
\hline & & & $(629-1394)$ & $(338-435)$ & $(72-94)$ & $(491-599)$ \\
\hline
\end{tabular}

A, B, C : The letters show differ between seasons (P <0.05); a, b, c The letters show differ between stations $(\mathrm{P}<0.05)$.

When the seasonal changes of $\mathrm{pH}$ values were examined according to the parameters of Sirakaraağaçlar Creek, the lowest value was 7.14 in winter and the highest value was 8.37 in summer, and both values were in $\mathrm{S} 2$ station. It can be stated that $\mathrm{pH}$ values are inversely proportional when compared with temperature values. $\mathrm{pH}$ values can vary depending on the amount of carbonate $\left(\mathrm{CO}_{3}{ }^{-2}\right)$, bicarbonate $\left(\mathrm{HCO}_{3}{ }^{-}\right)$, and free carbon dioxide $\left(\mathrm{CO}_{2}\right)$ in the water, but these changes can occur due to many factors. $\mathrm{pH}$ is inversely proportional to dissolved $\mathrm{CO}_{2}$ and directly proportional to $\mathrm{HCO}_{3}{ }^{-}$. The critical value of the presence of $\mathrm{CO}_{2}$ is $\mathrm{pH} 8$ [32]. Therefore, in our study, $\mathrm{CO}_{2}$ is active at $\mathrm{pH}$ 7.14 (winter), $\mathrm{HCO}_{3}{ }^{-}$is active at $\mathrm{pH} 8.37$ (summer). In the study carried out in the stream of S1karaağaç, 11.36 and $5.01 \mathrm{mg} / \mathrm{L} \mathrm{CO}_{2}$ [49], 4.58 and $26.04 \mathrm{~d}^{\circ} \mathrm{H} \mathrm{HCO}_{3}{ }^{-}$ values were obtained in the winter and summer seasons, respectively [50]. These results supported our study values. Oner and Celik [51], Şengün [52] and Dinçer [53] reported that $\mathrm{pH}$ values were 7.60 (in Gediz River), 7.42 (in Giresun Aksu Creek) and 7.92 (in Giresun Province Çanakçı Creek), respectively. In the studies carried out in river waters in different regions, it was found that the $\mathrm{pH}$ values were similar to our results. The $\mathrm{pH}$ of Sirakaraağaçlar Creek was in Class I and II Quality according to Continental Water Resources Quality Classification (Table 6).

Although the lowest conductivity was at S4 station with $20.11 \mu \mathrm{s} / \mathrm{cm}$, the highest conductivity value was found at S1 station with $1004.71 \mu \mathrm{s} / \mathrm{cm}$, and conductivity values generally changed below 1000 $\mu \mathrm{s} / \mathrm{cm}$, is shown in Table 1. Karsl1 [40] found the average conductivity value in the Sakaryaağaçlar stream as $12.25 \mu \mathrm{s} / \mathrm{cm}$ in the summer season and 8.64 $\mu \mathrm{s} / \mathrm{cm}$ in the autumn season. According to WHO standards, conductivity should be $1000 \mu \mathrm{s} / \mathrm{cm}$ in river waters [54]. The conductivity of water sources exceeding $1000 \mu \mathrm{s} / \mathrm{cm}$ is considered as a sign of pollution [45]. It is known that the electrical conductivity varies depending on the salts dissolved in water, their density and water temperature [55]. When 
the seasonal conductivity values of the stream were examined, it was found that the stations did not show a homogeneous distribution. The reason for this is primarily the difference in climatic conditions, the occasional merging of the water source with seawater, the variability of seasonal temperature and rainfall, the presence of other branches of the water supply can be shown. There are two most important reasons that affect our study results. The first of these, as the water level decreases in the late months of spring and in the summer, the mouth of the stream opening to the sea is closed, and the waters of the stream turn into freshwater in this period (station S1) [40]. The second reason is that precipitation varies according to the seasons. In Sinop province, the average of seasonal total rainfall between 1936-2019 was announced as 41.90 - $36.50 \mathrm{~mm}$ in spring-summer and 79.27 - 71.5 $\mathrm{mm}$ in autumn-winter, respectively [56]. The conductivity value was measured below expected due to the closed mouth of the stream in summer and the increase in precipitation in autumn. It was measured in studies that the conductivity value, which between 239 and $322 \mu \mathrm{s} / \mathrm{cm}$ in Emiralem Creek [57] and between 28 and $450 \mu \mathrm{s} / \mathrm{cm}$ in Trabzon province rivers [58]. Another study showed that the conductivity value of Ordu Ulugöl was $187.46 \mu \mathrm{s} / \mathrm{cm}$ [59].

$\mathrm{BOD}_{5}$ is the amount of oxygen that bacteria use to decompose OM under aerobic [32]. The correlation between BOD5 and OM is negative, and statistically significant relative to $\mathrm{P} \leq 0.05(\mathrm{r}=-0.326)$. $\mathrm{BOD}_{5}$ value was evaluated by many researchers in different regions. Verep, Serdar, Turan and Şahin [48], Dinçer [53] and Gedik, Verep, Ertuğrul and Fevzioğlu [60] evaluated that the average values of $\mathrm{BOD}_{5}$ were 2.40 $\mathrm{mg} / \mathrm{L}$ in Trabzon Iyidere, $1.85 \mathrm{mg} / \mathrm{L}$ in Rize storm Creek and $3.83 \mathrm{mg} / \mathrm{L}$ in Giresun Çanakçı Creek, respectively. Our findings were parallel with this study. In the Sirakaraağaçlar Creek, the lowest value $(0.84 \mathrm{mg} / \mathrm{L})$ and the highest value $(4.42 \mathrm{mg} / \mathrm{L})$ of $\mathrm{BOD}_{5}$ were determined at $\mathrm{S} 4$ station, and it was found to be Class II in terms of water quality according to Continental water resources. When the seasonal $\mathrm{BOD}_{5}$ values of the creek were examined, it was found that the $\mathrm{BOD}_{5}$ values were low in summer and high in autumn. This is an indication that the solubility of the gases is inversely proportional to the temperature and the DO value decreases when the temperature increases. Due to the high temperatures during the summer, the decrease in DO value and the reduction of bacteria working in an aerobic environment, and the slowing or decreasing of the organic disintegration process can be shown as the cause [61, 62]. The increase in $\mathrm{BOD}_{5}$ values towards autumn can be explained by the increased amount of DO due to seasonal decreases in water temperature and an increase in precipitation. Water temperature is a parameter that affects the optimal living conditions of aquatic organisms, as well as many biochemical processes, while directly changing dissolved oxygen and many physicochemical properties (Figure 3) of water in aquatic environments [63].

When the seasonal changes of $\mathrm{NH}_{4}{ }^{+}-\mathrm{N}$ values of Surakaraağaçlar Creek were examined, the lowest value was $0.01(\mathrm{mg} / \mathrm{L})$ in $\mathrm{S} 1, \mathrm{~S} 2$ and S3 stations, while the highest value was $0.33(\mathrm{mg} / \mathrm{L})$ in $\mathrm{S} 4$ station (Table 6). Ammonium is one of the nutrients that ensure the continuity of life. However, an excessive amount of nutrients in water resources causes pollution. In addition to providing the growth of algae in the water, it also adversely affects by reducing the amount of DO in the aquatic ecosystem [42]. When the $\mathrm{NH}_{4}{ }^{+}-\mathrm{N}$ values in the water source were examined, it was observed that they were low in the autumn and winter seasons. This is because; the amount of DO increases due to reduced water temperatures, and nitrification events accelerate and $\mathrm{NH}_{4}$ oxidizes during these seasons. Nitrification bacterial activity and concentrations rely on specific free ammonia concentration ( $\mathrm{NH}_{3} /$ biomass ratio), which is a function of temperature, $\mathrm{pH}$, ammonium concentration and nitrification biomass concentration. Therefore, in the nitrification process, the temperature is a key parameter that produces two opposite effects. These are bacterial activation and free ammonia inhibition $[64,65]$. At temperatures below $20^{\circ} \mathrm{C}$, nitrification proceeds at a lower rate, but continues at temperatures below $10^{\circ} \mathrm{C}[66-68]$. A temperature rise of $1{ }^{\circ} \mathrm{C}$ in the range of $10-29^{\circ} \mathrm{C}$ causes a $2 \%$ increase in the nitrification rate [64]. However, microorganisms responsible for nitrification (Nitrobacter and Nitro somonas) are extremely sensitive. They need a constant temperature of at least $12^{\circ} \mathrm{C}$, a suitable $\mathrm{C}$ : $\mathrm{N}$ : $\mathrm{P}$ ratio and a sufficient amount of added oxygen. In our study, the possibility of nitrification may occur due to the $\mathrm{pH}$ being $7.15-7.78$, the Nitrosomonas and Nitrobacter species being active at an optimum $\mathrm{pH}$ between 7 and 8 [69], and the temperature (12.45$13.37^{\circ} \mathrm{C}$ ) is not too low. Also, some phytoplankton species absorb ammonium is an important factor in reducing ammonium amount. This is an indication that $\mathrm{NH}_{4}$ is used in this cycle. $\mathrm{NH}_{4}{ }^{+}-\mathrm{N}$ values were measured in the range of 0.11-20.04 mg/L in Afyon Akarçay and $0.02-1.98 \mathrm{mg} / \mathrm{L}$ in Asi river by Kıvrak, Uygun and Kalyoncu [70], and Taşdemir and Göksu [46], respectively. These results were found to be consistent with the $\mathrm{NH}_{4}{ }^{+}-\mathrm{N}$ results in our study. According to the data of Turkey's Water Quality Management Regulation criteria Class of inland water 
resources (Table 6), the water quality of Sırakaraağaçlar creek was class I (high-quality water) for $\mathrm{BOD}_{5}$ and $\mathrm{NH}_{4}^{+}-\mathrm{N}$ values $[71,72]$.

$\mathrm{H}_{2} \mathrm{~S}$ is a colorless, toxic, volatile and flammable gas under normal conditions. $\mathrm{SO}_{4}{ }^{-2}$ ion in water sources is used as an oxygen source by sulphate reducing microorganisms in anaerobic environments, and $\mathrm{S}^{-2}$ ion is formed as a result of biochemical reactions. The $\mathrm{S}^{-2}$ ion reacts with hydrogen in water to form $\mathrm{H}_{2} \mathrm{~S}$ gas. In the study, when the $\mathrm{H}_{2} \mathrm{~S}$ values in the water source are examined, it is seen that the values are high in summer (Table 2). The reason for this is that the seasonal increase in water temperatures reduces the amount of dissolved oxygen. Moreover, the formation of oxygenfree products increases due to the fact that organic degradation is carried out by anaerobic bacteria $[32,73]$. In addition, $\mathrm{H}_{2} \mathrm{~S}$ may decrease if the $\mathrm{DO}$ value increases due to changes in water temperature. Since the final step of the $\mathrm{S}^{-2}$ cycle is $\mathrm{SO}_{4}^{-2}$, it is possible that a large proportion of the sulfur will be converted to sulfate owing to increased dissolved oxygen. S4 station is in the region where Aball village domestic wastes are mixed, and agricultural activities and animal husbandry are carried out. Therefore, domestic wastes and animal droppings containing organic substances, various fertilizers used in agriculture and pesticides were added in the stream waters. In the excess of organic matter, since the oxygen utilization rate in the stream is greater than the supply of oxygen, anaerobic conditions have emerged at certain distances in the stream, and $\mathrm{H}_{2} \mathrm{~S}$ has formed together with other gases as decomposition product $[33,74]$. Correlation values of $\mathrm{H}_{2} \mathrm{~S}$ were directly proportional to temperature and $\mathrm{NH}_{4}(\mathrm{r}=0.878, \mathrm{r}=0.516$, respectively; $\mathrm{P} \leq 0.001)$, It was inversely proportional to $\mathrm{DO}$ and $\mathrm{BOD}_{5}(\mathrm{r}=$ $0.489, \mathrm{r}=-0.650$, respectively; $\mathrm{P} \leq 0.001$ ), and were found to be very important (Table 5).

Considering the results of the study (except S4 station), it was determined that the lowest values of $\mathrm{OM}$ changes were in Winter and the highest values were in Summer(Table 2).OM values in this study differed from the studies were made by Gedik, Verep, Ertuğrul and Fevzioğlu in Rize Fırtına Creek [61], and Dinçer in Giresun Çanakçı Creek [53]. In our study, OM values of the creek ranged from 0.27 to $644 \mathrm{mg} / \mathrm{L}$. The fluctuations in the amounts of OM were decided, and it was concluded that this occurred due to seasonal changes of temperature, $\mathrm{pH}$ and precipitation. In 2014, Turkey in average rainfall of $641.6 \mathrm{~kg} / \mathrm{m}^{2}$, while 703.6 $\mathrm{kg} / \mathrm{m}^{2}$ (in $2015,691.5 \mathrm{~kg} / \mathrm{m}^{2}$ ) in average rainfall of Sinop was determined to be. It can be said that rains are very effective in the region $[74,75]$. When the correlation values of $\mathrm{OM}$ were examined (Table 5), it was found that it was directly proportional to temperature, TSS and $\mathrm{pH}(\mathrm{r}=0.681, \mathrm{r}=0.994$ ve $\mathrm{r}=0.629$, respectively), and they were statistically significant $(\mathrm{P} \leq 0.001)$.TSS is known as the total of soluble and insoluble solids in water and they are suspended in water. It is generally composed of colloidal organic materials, sediment materials, sludge or clay minerals. Many substances (TSS) such as clay, organic substances, microscopic organisms, calcium carbonate, aluminum hydroxide, iron hydroxide can hang in the water. When organic substances break down, they can cause an increase in suspended substances that are soluble and have low solubility. Moreover, mixed organic substances (naphthalene and phenols etc.) and others can cause $\mathrm{pH}$ rise in water [76]. The area of the S1karaağaçlar Stream close to the sea is in the region where the swamps are most intense. Moreover, it is in the region where Tourism is effective because it is a residential area. For this reason, OM, TSS (except spring) and conductivity values were determined at the highest stations S1 and S2. Organic materials derived from detritus (rotting plant parts) predominate in marshes. The overall low permeability of soft fine-grained sediments limits the movement of water in the soft sediment layer [77] and causes the accumulation of organic substances.

Suspended solids are an important parameter for waters; as the amount of solids in the water increases, the permeability of the water decreases, and the solids cause adverse conditions for aquatic organisms [78]. Taşdemir and Göksu [46] found the TSS value as 1$381 \mathrm{mg} / \mathrm{L}$ in the Asi River, while Tepe and Mutlu [37] found the TSS value as $1.75 \mathrm{mg} / \mathrm{L}$ in Hatay Harbiye Spring water. TSS values in this study were established to be low values according to literature studies (Table 2).TSS values showed an increase and decrease in seasonal changes, and it can be said that it is due to water flow rate and precipitation. The reason for the fact that the TSS values in summer is higher compared to other seasons is that the evaporation and the input of urban wastewater are high. Correlation values of TSS were found to be directly proportional to temperature, $\mathrm{pH}, \mathrm{H}_{2} \mathrm{~S}$ and $\mathrm{OM}(\mathrm{r}=0.681, \mathrm{r}=0.606, \mathrm{r}=0.545$ ve $\mathrm{r}=0.994$, respectively), and this correlation $(\mathrm{P} \leq 0.001)$ were to be very important statistically (Table 5).TSS values of the creek (Table 6), according to Turkey's Water Quality Management Regulations criteria according to internal water resources were clean water. According to the Eutrophication Control Limit Values data for lakes and marshes, the TSS value for natural protected areas is $5 \mathrm{mg} / \mathrm{L}[71,72]$. 
Table 5.Correlation between Coliform Bacteria and Physicochemical Parameters.

\begin{tabular}{|c|c|c|c|c|c|c|c|c|c|c|}
\hline & T.Coliform & F.Coliform & Temperature & DO & $\mathrm{pH}$ & Conductivity & $\mathrm{BOD}_{5}$ & $\mathrm{NH}_{4}^{-}-\mathrm{N}$ & $\mathrm{H}_{2} \mathrm{~S}$ & $\mathrm{OM}$ \\
\hline F.Coliform & $0.985 * * *$ & & & & & & & & & \\
\hline Temperature & $0.379 * *$ & $0.38]^{* *}$ & & & & & & & & \\
\hline DO & $-0.752 * * *$ & $-0.757 * * *$ & -0.224 & & & & & & & \\
\hline $\mathrm{pH}$ & $0.343^{*}$ & $0.404 * *$ & $0.783 * * *$ & $-0.445^{* *}$ & & & & & & \\
\hline Conductivity & $-0.554 * * *$ & $-0.535^{* * *}$ & -0.154 & $0.429 * *$ & -0.138 & & & & & \\
\hline $\mathrm{BOD}_{5}$ & -0.234 & -0.188 & $-0.638 * * *$ & 0.280 & $-0.329 *$ & 0.139 & & & & \\
\hline $\mathrm{NH}_{4}^{-}-\mathrm{N}$ & $0.791 * * *$ & $0.732 * * *$ & $0.590 * * *$ & $-0.490 * * *$ & 0.255 & $-0.428 * *$ & $-0.427 * *$ & & & \\
\hline $\mathrm{H}_{2} \mathrm{~S}$ & $0.545^{* * *}$ & $0.574 * * *$ & $0.878 * * *$ & $-0.489 * * *$ & $0.831 * * *$ & -0.188 & $-0.650 * * *$ & $0.516 * * *$ & & \\
\hline $\mathrm{OM}$ & -0.132 & -0.083 & $0.681 * * *$ & 0.158 & $0.629 * * *$ & $0.336^{*}$ & $-0.326^{*}$ & -0.000 & $0.570 * * *$ & \\
\hline TSS & -0.123 & -0.076 & $0.681 * * *$ & 0.181 & $0.606 * * *$ & $0.335^{*}$ & $-0.308 *$ & -0.026 & $0.545 * * *$ & $0.994 * * *$ \\
\hline
\end{tabular}

$\mathrm{P} \geq 0.05 ;(*) \mathrm{P} \leq 0.05 ;(* *) \mathrm{P} \leq 0.01 ;(* *) \mathrm{P} \leq 0.001$

Table 6.Quality of Sırakaraağaçlar Creek according to inland water resources classes.

\begin{tabular}{|c|c|c|c|c|c|c|}
\hline \multirow{2}{*}{ Water quality parameters } & \multicolumn{4}{|c|}{ Water quality Classes } & \multicolumn{2}{|c|}{ Sırakaraağaçlar Creek } \\
\hline & Class I & Class II & Class III & Class IV & (Min.-Max.) & Class \\
\hline Temperature $\left({ }^{\circ} \mathrm{C}\right)$ & $\leq 25$ & $\leq 25$ & $\leq 25$ & $>30$ & $(12.45-26.98)$ & I - III \\
\hline $\mathrm{DO}(\mathrm{mg} / \mathrm{L})$ & $>8$ & 6 & 3 & $<3$ & $(5.23-1.26)$ & II - IV \\
\hline $\mathrm{pH}$ & $6.5-8.5$ & $6.5-8.5$ & 9 & 6-9 Outside & $(7.14-8.37)$ & I - II \\
\hline Conductivity $((\mu \mathrm{S} / \mathrm{cm})$ & $<400$ & 1000 & 3000 & $>3000$ & $(20.11-1004.71)$ & I -II \\
\hline $\mathrm{BOD}_{5}(\mathrm{mg} / \mathrm{L})$ & 4 & 8 & 20 & $>20$ & $(0.84-4.42)$ & II \\
\hline $\mathrm{NH}_{4}-\mathrm{N}(\mathrm{mg} / \mathrm{L})$ & 0.2 & 1 & 2 & $<2$ & $(0.01-0.33)$ & I - II \\
\hline $\mathrm{OM}(\mathrm{mg} / \mathrm{L})$ & 5 & 8 & 12 & $>12$ & $(8.20-228.41)$ & II - IV \\
\hline TSS (mg/L) & 5 & \multicolumn{3}{|c|}{ Natural protected area and recreation } & $(0.014-0.415)$ & \\
\hline T.Coliform (cfu)/100 mL) & $\leq 100$ & 20000 & 100000 & $>100000$ & $(35.88-1263.55)$ & I - II \\
\hline F.Coliform (cfu)/100 mL) & $\leq 10$ & 200 & 2000 & $>2000$ & $(27.33-1020.22)$ & II - III \\
\hline
\end{tabular}

Class I: Clean. Class II: Slightly contaminated. Class III: Contaminated and Class IV: Highly contaminated. 
Coliforms are a broad variety of bacteria. Coliform group of bacteria in the Enterobacteriaceae family, rodshaped, non-spore-forming, gram-negative by fermentation of lactose at $35^{\circ} \mathrm{C}$ in 48 hours are bacteria that produce gas. Coliform bacteria are most frequently seen in the intestines of animals, as well as in plants and soil $[34,79]$. The presence of F. coliform bacteria in water sources demonstrates that water is in contact with fecal waste, which designates that water sources are polluted with many harmful, dangerous and disease-causing bacteria, protozoa, parasites and viruses [34]. The lowest value of $\mathrm{T}$. coliform and $\mathrm{F}$. coliform in Sirakaraağaçlar Creek is monitored in S1 station with 33.88 and $27.33 \mathrm{cfu} / 100 \mathrm{ml}$, respectively and the highest value is established in S4 station with 1263.55 and $1020.22 \mathrm{cfu} / 100 \mathrm{ml}$, respectively. It was determined that there was a village settlement near the S4 station, there were agricultural areas and grazing areas of animals around the village. In addition, it is known that the sewage system of the village is mixed from this area into the stream. The reason why T.coliform and F. coliform values were higher than other stations was explained by the fact that human and animal origin wastes were mixed into the stream. Coliform amount in the Dicle river was found as 2.10$4.02 \log _{10} \mathrm{cfu} / \mathrm{ml}$ [80], whereas the amount of coliform and $E$. coli in the drinking water of Bitlis province was calculated to be in the range of 501-5000/100ml [81]. F.coliform load were found to be $>1100 / 100 \mathrm{ml}$ in Çanakkale Sarıçay Stream and Kahramanmaraş Aksu Creek by Çolakoğlu and Çakır [82], and Toroğlu, Toroğlu and Alaeddinoğlu [83], respectively. Coliform values were different from the results of previous studies. This was due to the difference in place and time.

The seasonal variation of $\mathrm{F}$. coliforms was determined to be in parallel with $\mathrm{T}$. coliforms. It is viewed that most of $T$. coliforms are generally occurred of $F$. coliforms, which are not wanted to be observed in the waters. Seasonal changes in Creek have also viewed both T. coliforms and F.coliforms contamination. This is an indication that creek is in contact with human and animal feces throughout the year. T. coliform and F. coliform load in Creek was identified to be higher in summer compared to other seasons. The reasons for the increase of coliform concentrations can be expressed as the increase of water temperature owing to seasonal temperature change, the formation of appropriate reproductive environment for microorganisms, the decrease in the amount of seasonal precipitation and the increase of water inflow from urban sewage into natural water resources. In the transition from summer to winter, the decrease in T. coliform and F. coliform loads was caused by the decrease in water temperature.
Moreover, the reduction in their load in the water was owing to increased precipitation. According to the results found from the study area, T. coliform value was discovered to be highest at S4 station in all seasons. The reason for this is the change in water flow rate and quantity, and also that the station is on the route of the animals. When seasonal $\mathrm{T}$. coliform values of the stream were compared, S1 station was found to be lower than other stations. This situation was interpreted as the result of the increase in salinity value due to marine impact. One of the most important factors affecting our study results is that as the water level decreases in late spring and summer, the mouth of the creek closed to the sea and the waters of the stream turn into freshwater during this period [40]. The other is that the amount of precipitation in the region is high $[74,75]$. When $\mathrm{T}$. coliform and F. coliform correlation values $(\mathrm{P} \leq 0.001)$ wereachieved (Tablo 6), it was decided that it was directly proportional with each other $(\mathrm{r}=-0.985)$ and with $\mathrm{NH}_{4}(\mathrm{r}=-0.791 ; \mathrm{r}=-$ 0.732 , respectively), $\mathrm{H}_{2} \mathrm{~S} \quad(\mathrm{r}=-0.545 ; \quad \mathrm{r}=-0.574$, respectively), inversely proportional with DO ( $\mathrm{r}=-$ $0.752 ; \mathrm{r}=-0.757$, respectively) and conductivity ( $\mathrm{r}=-$ $0.554 ; \mathrm{r}=-0.535$, respectively), and these relationships are quite important. The average value of physical parameters andcoliforms were compared with "Environmental Legislation", "Regulation on Water Pollution Control" and "Quality Criteria According to Classes of Inland Water Resources", and were shown in Table $6[71,72]$ It was determined that Sırakaraağaçlar Creek were more or less (class II-IV) contaminated water in terms of DO parameter, and contaminated or highly contaminated water in terms of $\mathrm{H}_{2} \mathrm{~S}$ parameter, and slightly soiled or contaminated (class II-III) water in terms of T. coliform (class I-II) and F. coliform (class II-III) values.

\section{Conclusions}

In the developing world, due to the increase in environmental sensitivity, it is known that although necessary measures are taken for water pollution, it is not sufficient. It is very important to increase the studies on the quality and pollution of water resources and to determine the current conditions of water resources and the sources of pollutants. The water of Sırakaraağaçlar Creek passes through settlements and agricultural areas until it reaches the sea. If the current state of the water quality parameters of the water source is not improved and maintained, the possibility of an increase in pollution load is inevitable in the following years. Also, adverse conditions that may affect aquatic life and human health may arise in the ecosystem and water basin. 
When the data obtained from this study were evaluated, it was determined that DO value of water source was low and $\mathrm{H}_{2} \mathrm{~S}, \mathrm{~T}$. coliform and $\mathrm{F}$. coliform values were high. This reinforces the possibility that eutrophication may start or increase in the water source. It is thought that the amount of suspended solids, temperature, the load of $\mathrm{OM}$ and other pollutants affect the low oxygen values in the water source. Controlling and continuous monitoring of these parameters supports the possibility that the DO value may naturally return to normal values. One of the measures that can be taken for hydrogen sulfide pollution, which is one of the pollution types in our study, is to correct the sewage infrastructure of the settlements around the creek. The second is to take measures to reduce a load of OM before the discharge of wastewater. The main source of coliform pollution is wastewater in sewers. These bacteria can cause serious diseases for human health. It is evident that the continuous monitoring of the coliform bacteria load of the water source and the installation of sewage treatment systems will be an effective measure to prevent pollution. The current status of Sırakaraağaçlar Creek should be monitored periodically and necessary measures ought to be taken to protect and improve it. In addition, the water source should be kept under control for the substances that may increase the load of suspended solids entering the water sources from the surrounding settlements and agricultural lands.

In order to ensure the sustainability of water resources; prevention of further degradation of aquatic environments, and improvement works, good protection of water resources for long-term use, further emphasizing the seriousness and importance of the issue should be among our goals. The idea of dissemination of the management concept on the basis of the river basin, which is the main objective of the European Union water framework directive, should be adopted. The quality of life and sustainability of aquatic organisms will be possible with the quality and cleanness of natural waters.

\section{Acknowledgement}

The data of the Master thesis "Investigation of some physicochemicaland microbiological parameters in Karasu and Sırakaraağaçlar stream" was used. We owe our thanks for his contribution to Institute of the Natural Science of Sinop University.

\section{Conflicts of interest}

The authors state that did not have a conflict of interests.

\section{References}

[1] Kanownik W. and Rajda W. Samooczyszczanie wody potoku Pychowickiego, Zesz. Prob. Post. Nauk Rol., 561 (2011) 81-91.

[2] Napieralska A. and Gołdyn R. Sanitary Analyses of Runoff Water a River, Pol. J. Environ. Stud., 22 (2) (2013) 481-486.

[3] Bogdal A., Kowalik T., Ostrowski K. and Skowron P. Seasonal variability of physicochemical parameters of water quality on length of Uszwica river, J. Ecol. Eng., 17 (1) (2016) 161-170.

[4] Küçük S. Investigation of Water Quality Parameters of the Büyük Menderes River for Fisheries, Adü. Ziraat Derg., (2007) 7-13.

[5] Gündoğdu A., Gültepe E., and Çarlı U. Determination of Anionic Detergent Concentration of Karasu Stream in Sinop (Turkey), Turk. J. Agric.- Food Sci. Tech., 6-1 (2018) 112-123.

[6] Wu J., Li P., Qian H., Duan Z. and Zhang X. Using correlation and multivariate statistical analysis to identify hydrogeochemical processes affecting the majör ion chemistry of waters: a case study in Laoheba phosphorite mine in Sichuan, China, Arab J. Geosci., 7 (2014) 3973-82.

[7] Mostafa A.H., Al-Wasify R.S., Sayed A.M. and Haroun B.M. Microbiological and physicochemical evaluation of groundwater in Egypt, Int. J. Environ. Sust., 2 (2013) 1-10.

[8] Singh A.K., Das S., Singh S., Pradhan N., Gajamer V.R., Kumar S., Lepcha Y.D. and Tiwari H.K. Physicochemical Parameters and Alarming Coliform Count of the Potable Water of Eastern Himalayan State Sikkim: An Indication of Severe Fecal Contamination and Immediate Health Risk, Front. Public Health, 7 (2019) 174.

[9] Hamzah A., Kipli S.H., Ismail S.R., Una R. and Sarmani S. Microbiological study in coastal water of Port Dickson, Sains Malays., 40-2 (2011) 9399.

[10] WHO. Guidelines For Drinking Water Quality, Volume 2, Health Criteria and Other Supporting Information, Second ed., World Health Organization (WHO), Geneva, (1997) 65.

[11] Abreu-Acosta N. and Vera L. Occurence and removal of parasites, enteric bacteria and faecal contamination indicators in wastewater natural reclamation systems in Tenerife- Canary Islands, Spain, Ecol. Eng.,37 (2011) 496-503.

[12] Al-Bahry S., Mahmoud I.Y., Al-Belushi K.I.A., Elshafie A.E., Al-Harthy A. and Bakheit C.K. Coastal sewage discharge and its impact on fish with reference to antibiotic resistant enteric 
bacteria and enteric pathogens as bio-indicators of pollution, Chemosphere, 77 (2009) 1534-1539.

[13] Berber I. and Avşar C. Investigating Some Microbial Pollution Parameters of Seawater and Mussels (Mytilus galloprovincialis, Lamarck 1819) of Sinop. Black Sea Coastal Zone, Turkey, Sains Malays., 43 (12) (2014) 1835-1842.

[14] Ward D.R. and Hackney C. Microbiology of marine food products, New York: Published by Van Nostrand Reinhold, 1991; 443.

[15] Kilinc B. and Besler A. The occurrence of enteric bacteria in marine environment and pollution, Mar. Sci. Tech. Bull., 3 (2) (2014) 39-43.

[16] Elmanama A.A., Afifi S. and Bahr B. Seasonal and spatial variation in the monitoring parameters of Gaza Beach during 2002-2003, Environ. Res., 101 (2006) 25-33.

[17] Acehan G. Investigation of Microbiological Pollution Potential of Drinking Waters. Master Thesis, Cukurova University, Institute of Science, Adana, (2007) 235.

[18] Elmacı A., Teksoy A., Topaç F.O., Özengin N. and Başkaya H.S. Monitoring of Seasonal Variation of Microbial Quality in Lake Uluabat. Uludağ University, J. Eng.-Archit. Faculty, 13 (1) (2008) 93-103.

[19] Aksu H. Evaluation of Drinking Water Microbiological Risks. Istanbul and Water Symposium: Discussions and Forum, Istanbul, (2004).

[20] Fakir Y. Investigation of water quality parameters in Denizli water supply network according to time and location. Master's Thesis, Pamukkale University, Institute of Science, Denizli, (2012) 142.

[21] Ayaz E. Investigation on cryptosporidium parvum by using molecular technics in water samples collected from provinces of Giresun and Samsun. Master Thesis, Ordu University, Institute of Science, Ordu, (2015) 140.

[22] Hagendorf U., Diehl K., Feuerpfeil I., Hummel A. and Szewzyzk R. Retention of microbiological organisms in constructed wetlands. In: Proceedings of the Seventh International Conference on Wetland Systems for Water Pollution Control., Gainesville: IWA and University of Floryda, (2000) 391.

[23] Sigua G.C., Palhares J.C.P., Kich J.D., Mulinari M.R., Mattei R.M., Klein J.B., Müller S. and Plieske G. Microbiological Quality Assessment of Watershed Associated with Animal-Based Agriculture in Santa Catarina, Brazil, Water Air Soil Pollut., 210 (2010) 307.

[24] Salyers A.A. and Whitt D.D. Microbes and a human in imbalance: infectious diseases. In:
Microbiology. Diversity, pathogenicity and environment. PWN, Warsaw, [In Polish], (2012).

[25] Augustyn L., Babula A., Joniec J., StanekTarkowska J., Hajduk E. and Kaniuczak J. Microbiological Indicators of the Quality of River Water, Used for Drinking Water Supply, Pol. J. Environ. Stud., 25 (2) (2016) 511-519

[26] Ozaner F.S. Sinop Batısındaki Ekosistemler ve İlginç Yerşekillerinin Jeomorfolojisi, Ekoturizm Yönünden Önemi. TÜBİTAK Yer Deniz Atmosfer Bilimleri ve Çevre Araştırma Grubu, Ankara, (1998) 19.

[27] Ustaoğlu S., Yardım Ö. and Tirıl A. General Characteristics and Conservation Problems of Wetlands (Sarıkum and Karagöl-Aksaz) in Sinop. Süleyman Demirel University, Protected Natural Areas Symposium, 8-10 September 2005, Isparta, (2005) 267.

[28] GEUPD. T.C. Sinop Governorate, Environment and Urbanization Provincial Directorate (T.C.SGEUPD). Sinop province, 2018 Environmental Status Report. (2019).

[29] Karsl1 Z. and Aral O. Population Age, Sex Structure and Growth of Aphanius danfordii (Boulenger, 1890) to Sirakaraağaçlar Stream, Turkey. J.Anim.Vet. Adv., 9 (10) (2010) 14271431.

[30] APHA. Standard methods for the examination of water and waste water. 19th edition. American Public Health Association (APHA) Inc., New York, (1965) 1193.

[31] APHA. Standard Methods for the Examination of Water and Wastewater, 15th ed.; APHA (American Public Health Association): Washington, D.C, USA, (1981) 85- 99, 773-779, 786-828.

[32] Egemen Ö. and Sunlu U. Water Quality, Ege University, İzmir, Turkey, E.Ü.F.F. Press., (1996) 153.

[33] TSI. Drinking and Use Water Standards, Turkish Standards Institute: TSI (Türk Standartları Enstitüsü, İçme ve Kullanma Suları Standartları), (2005).

[34] Halkman A.K. Food Microbiology Applications, Başak Typography (Gida Mikrobiyolojisi Uygulamaları Merck., Ed: A. K. Halkman, Başak Matbaacılık), Ankara, Türkiye, 89 (124) (2005) 358.

[35] Cirik S, Cirik Ş. Limnology. Ege University, Faculty of Fisheries Press, Izmir, Turkey, (2008) 166.

[36] Gürel E., Determination of Porsuk Stream Water Quality, Master Thesis. Eskişehir Osmangazi University, Eskişehir, Turkey, (2011). 
[37] Tepe Y. and Mutlu E. Physico-Chemical Characteristics of Hatay Harbiye Spring Water. D. U. Journal of the Institute of Science, 6 (2004) 77-88.

[38] Bulut C., Akçimen U., Uysal K., Küçükkara R., Savaşer S., Tokatlı C., Öztürk G.N. and Köse E. Water Qality Of Kestel Creek (Burdur) and Assesment For Salmonid Culture, J. Sci. Technol. Dumlupinar Univ, 28 (2012) 1-10.

[39] Y1ldı İ. Determination of the Water Quality and Pollution Level of Gelevera Creek. Master Thesis, Giresun University, Institute of Sciences, Department of Biology, Giresun, (2013) 92.

[40] Karsl1 Z. Some Biological Characteries of the Mosquitofish (Aphanius Chantrei) Population In The Sırakaragaçlar Stream (Sinop-Akliman). Master Thesis, Ondokuz May1s University Institute of Science, Samsun (2007) 45.

[41] Gündoğdu A. Investigation of Anionic Detergents Pollution in shore of Sinop (Master's thesis). Ondokuz Mayis University, Samsun, Turkey, (1995) 60.

[42] Tayhan N. Periodic Monitoring of Physicochemical Water Quality of Uzuncayir Dam Lake (Tunceli) . Master Thesis, Tunceli University Institute of Science and Technology, Tunceli, (2012) 79.

[43] WHO. World Health Organization (WHO). Diarrhoeal Disease. ( 2018).

[44] EC. "Directive 2000/60/EC of the European Parliament and of the Council of 23 October 2000 establishing a framework for Community action in the field of water policy", Official Journal of the European Communities (EC), (2000).

[45] Kara, C., Çömlekcioğlu, U. Karaçay (Kahramanmaraş)'ın Kirliliğinin Biyolojik ve Fiziko-Kimyasal Parametrelerle İncelenmesi, KSÜ Fen ve Müh. Dergisi, 7(1) (2004) 7.

[46] Taşdemir, M. and Göksu, Z.L. Some Water Quality Criteria of Asi River (Hatay), Ege J. Fish. Aquat. Sci., 18(1-2) (2001) 55-64.

[47] Tepe Y., Mutlu E., Ateş A. and Başusta N. Water Quality of Samandağ Karamanlı Lake (Hatay), Turk. J. Aquat. Life, 3 (2004) 408-414.

[48] Verep B., Serdar O., Turan D. and Şahin C. Determination of Water Quality in terms of Physico-Chemical Structure of the River Iyidere (Trabzon), Ecology, 14(57) (2005) 26-35.

[49] Gültepe E. Investigation of Anınic Detergent Pollution In Karasu and Sirakaraağaçlar Stream. Master Thesis, Sinop University Institute of Science Sinop, (2016) 116.

[50] Çarlı U. Investigation Ofsome PhysicoChemicaland Microbiological Parameters In Karasu and Sırakaraağaçlar Stream. Master
Thesis. Sinop University Institute of Science, Sinop, (2015) 136.

[51] Oner O. and Celik A. Investigation of some pollution parameters in water and sediment samples collected from the lower Gediz river basin, Ecology, 20 (78) (2011) 48-52.

[52] Şengün E. Determination of The Water Quality and Pollution Level of Aksu Creek. Master Thesis, Giresun University, Giresun, Turkey, ( 2013 ) p 66.

[53] Dinçer S. Determination of the Water Quality and Pollution Level of Çanakçı Creek, Master's Thesis, Giresun University, Giresun, Turkey (2014).

[54] Leong S.S., Ismail J., Nurdiyana A., Denil N.A., Shahrul R., Sarbini S.R., Wafri Wasli W. and Debbie A. Microbiological and PhysicochemicalWater Quality Assessments of River Water in an Industrial Region of the Northwest Coast of Borneo, Water, 10 (2018) 1648

[55] Er C.B. Some physicochemical and microbiological properties of drinking water in Kilis province (Master's Thesis), Kilis 7 Aralık University, Kilis, Turkey, (2014).

[56] MAFGDM., T.C. Ministry of Agriculture and Forestry General Directorate of Meteorology. General Statistical Data of Our Provinces 19361919. Retrieved June 03, 2020.

[57] Sukatar A., Yorulmaz B., Ayaz D. and Barlas M. Investigation of Some Physio-chemical and Biological (Benthic Macroinvertebrata) Features of Emiralem Stream (Izmir-Menemen), SDÜ. Fen Bil. Ens. Derg., 10 (3) (2006) 328-333.

[58] Gültekin F., Ersoy A.F. Hatipoğlu E. and Celep S., Determination of Water Quality Parameters in Wet Season of Surface Water in Trabzon, Ecology, 21(82) (2012) 77-88.

[59] Taş B., Candan, A.Y., Can, Ö. and Topkara, S. Ulugöl (ORDU)'nün Bazı Fiziko-Kimyasal Özellikleri, Journal of Fisheries Sciences, 4 (3) (2010) 254-263.

[60] Gedik K., Verep B., Ertuğrul T. and Fevzioğlu S. Determination of Water Quality of Firtına Stream (Rize) in terms of Physico-Chemical Structure, Ecology, 19-76 (2010) 25-35.

[61] Egemen Ö. Environment and Water Pollution, ., İzmir, Turkey: EÜFF Press, 2000; 120.

[62] Şakar S. Çevre Mikrobiyolojisi Ders Notları (2019-2020 Öğretim Yılı), Yıldız Teknik Üniversitesi İnşaat Fakültesi Çevre Mühendisliği Bölümü, İstanbul (2020) 138.

[63] Hasançavuşoğlu Z. and Gündoğdu A. Investigation of Anionic Detergent Pollution in 
Sarıkum Lake (Sinop), Turk. J. Agric.- Food Sci. Tech., 7 (11) (2019) 1825-1833.

[64] Fdz-Polanco F., Villaverde S. and García P.A. Temperature effect on nitrifying bacteria activity in biofilters: Activation and free ammonia inhibition, Wat. Sci. Tech., 30 (11) (1994) 121130.

[65] Kaplan D., Wilhelm R. and Abeliovich A. Interdependent environmental factors controlling nitrification in waters, Water Science and Technology. 42 (1-2) (2000) 167-172.

[66] Schlegel H.G. Allgemeine Mikrobiologie, Newyork: Thieme Verlag, 1985; 571.

[67] Kirmeyer G.J., Odell L.H., Jacangelo J., Wilczak A. and Wolfe R. Nitrification Occurrence and Control in Chloraminated Water Systems, Denver, Colo.: AwwaRF and AWWA, 1995;

[68] Sivri N., Karaçam H. and Feyzioğlu M. Nitrifying Bacterial Activity In South Eastern Black Sea (Coast of Sürmene), Tr. J. of Biology, 22 (1998) 299-306.

[69] EPA. Nitrification. U.S. Environmental Protection Agency Office of Ground Water and Drinking Water Standards and Risk Management Division, 1200 Pennsylvania Ave., NW Washington DC 20004. August 15 (2002).

[70] Kivrak E. Uygun A. and Kalyoncu H. Application of Diatom Indices to Assess Water Quality of the Akarçay Stream (Afyonkarahisar, Turkey). AKU J. Sci.,12 (2012) 27-38.

[71] SWQMR. Regulation on the surface water quality management, Number of official gazette: 29327 (2015).

[72] SWQMR Regulation on the surface water quality management, Number of official gazette: 29797 (2016).

[73] Öztürk M. Hydrogen sulfide gas formation in sewerage and Its effects on health. (Kanalizasyonda Hidrojen Sülfür Gazı Oluşumu ve Sağlı Üzerine Etkileri), Ministry of Environment and Forestry, Ankara, (2006) 13. Retrieved April 4, 2018.
[74] SGEUPD. T.C. Sinop Governorate, Environment and Urbanization Provincial Directorate (T.C.SGEUPD), Sinop province, 2014 Environmental Status Report. (2015).

[75] SGEUPD. T.C. Sinop Governorate, Environment and Urbanization Provincial Directorate (T.C.SGEUPD), Sinop province, 2015 Environmental Status Report. (2016).

[76] Uslu O. and Türkman A. Water Pollution and Control. TC. Prime Ministry General Directorate of Environment Publications, Education series, (1987) 364.

[77] EPA. US Environmental Protection Agenc, Region 2. Berry's Creek Study Are Proposed Plan. Part of the Ventron/Velsicol Superfund Site. New York, May (2018) 10007-1866. Retrieved June 4, 2020.

[78] Dihkan M., Karslı F. and Güneroğlu A. Mapping Distribution of Total Suspended Matter Concentration In Coastal Black Sea Waters. Chamber of Survey and Cadastre Engineers (TMMOB), 13th Turkey Scientific and Technical Congress, Ankara, (2011).

[79] Şengül F., Türkman A. Water and Wastewater Analysis. Chamber of Environmental Engineers (TMMOB), İzmir, (1998) 152.

[80] Vural A. And Erkan M.E. 2006. Microbiological Quality Parameters in Fish of Dicle (Tigris) River Near Diyarbakır City, Dicle Medical Journal, 33(3) (2006) 153-156.

[81] Alemdar S., Kahraman T., Ağaoğlu S. and Alişarlı M. Some Microbiological and Physicochemical Properties of Drinking Water in Bitlis District, Ecology, 19 (73) (2009) 29-38.

[82] Çolakoğlu F.A. and Çakır F. Microbiological Quality in Sarıçay Stream, Canakkale University Fisheries Faculty, (2003) 305-312.

[83] Toroğlu E., Toroğlu S. and Alaeddinoğlu F. Water Pollution in the Aksu River (Kahraman Maraş), $J$. Geogr. Sci., 4(1) (2006) 93-103. 